\title{
The Application of Behaviour-modifying Chemicals to Contain Infestations of the Mountain Pine Beetle, Dendroctonus ponderosae1,2
}

by

\author{
J.H. Borden ${ }^{3}$, L.J. Chong ${ }^{3}$, K.E.G. Pratt ${ }^{4}$ and D.R. Gray ${ }^{5}$
}

\begin{abstract}
Five replicates of paired forest blocks containing lodgepole pine, Pinus contorta var. Iatifolia Engelm., infested by the mountain pine beetle, Dendroctonus ponderosae Hopkins, were chosen in the spring of 1982 in various interior British Columbia locations. Within the experimental block of each pair, one lodgepole pine every $50 \mathrm{~m}$ ( 4 trees/ha) was baited with the attractive semiochemicals myrcene, trans-verbenol and exo-brevicomin. The baiting program caused the attack in 1982 to be concentrated in and around the baited trees, whereas it was more dispersed in the control blocks. The overall ratio of 1982: 1981 attacked trees was 2.5 in the baited blocks and 1.8 in the controls, suggesting that dispersal of beetles out of the baited blocks was inhibited. Baiting of trees with semiochemicals is recommended to contain infestations within prescribed boundaries when sanitation-salvage logging cannot be completed prior to mid-summer flight of emergent brood beetles.
\end{abstract}

\section{Résumé}

Cinq répétitions de blocs forestiers pairés de pin lodgepole (Pinus contorta var. latifolia Engelm.) infesté par le (Dendroctone ponderosa Hopkins) furent choisies au printemps 1982 dans divers sites de l'intérieur de la Colombie Britanique. Dans le bloc expérimental de chaque paire, un pin à tous les cinquante mètres (4 arbres/ha) a été traité au "myrcene", au "transverbenol" et à l'"exo-brevicomin" pour servir d'élément attractif. Le traitement d'appât a causé en 1982 une attaque concentrée autour des arbres appâtés, alors que l'attaque a été plus dispersée dans les blocs de contrôle. Le rapport d'arbres attaqués de 1982 sur 1981 , étant de 2.5 dans les blocs appâtés et de 1.8 dans le contrôles, suggère que la dispersion du dendroctone en dehors des blocs d'appâts était inhibée. Le traitement d'appât est recommandé pour contenir certaines infestations à l'intérieur des limites prescrites lorsque la récupération des bois ne peut être réalisée avant le vol de la mi-été des nouvelles dendroctones.

\section{Introduction}

The mountain pine beetle, Dendroctonus ponderosae Hopkins, is in outbreak throughout much of Western North America (Van Sickle 1982; McGregor 1982). One means of inhibiting small infestations from expanding to outbreak proportions is sanitation-salvage cutting, whereby infested trees with live brood beetles as well as susceptible, uninfested trees are removed from the forest (Safranyiket al. 1974). Such harvesting may be hindered by the absence of roads, poor road conditions, lack of adequate pre-harvest inventory, problems in issuing cutting permits, preoccupation of contractors with

\footnotetext{
Coleoptera: Scolytidae

2Research supported by the Science Council of British Columbia and the Natural Sciences and Engineering Research Council of Canada Operating Grant A3881 and Open Strategic Grant G1039.

${ }^{3}$ Centre for Pest Management. Dept. of Biological Sciences, Simon Fraser University, Burnaby, BC V5A 1 S6.

${ }^{4}$ Bulkley District. Prince Rupert Region, BC Forest Service, Smithers, BC VOJ 2 NO

5 Protection Branch, Nelson Forest Region, BC Forest Service, Nelson, BC V1L 4C6.
}

other priorities, or poor timber markets. If the cut cannot be made prior to emergence of the brood beetles, an infestation may intensify and expand. This problem often occurs in infestations in lodgepole pine, Pinus contorta var. latifolia Engelm., and ponderosa pine. $P$. ponderosa Laws., in the interior of British Columbia.

A complex of three semiochemicals (message-bearing or behaviour-modifying chemicals) is known to mediate mass attack by D. ponderosae in hard pines in BC (Connet al. 1983; Borden et al. 1983a). These chemicals are the host tree monoterpene, myrcene, and two aggregation pheromones, the female-produced trans-verbenol, and the male-produced exo-brevicomin. They can be effectively used to induce attack on trees baited with them, as well as to concentrate attack on nearby surrounding trees (Borden et al, 1983a,b). A similar effect has been domonstrated with semiochemicals used by other bark beetles, e.g. the Douglas-fir beetle, Dendroctonus pseudotsugae Hopkins (Ringold et al. 1975), and the spruce beetle, $D$. rufipennis (Kirby) (Dyer 1975). These results led us to adapt Pitman's (1973) strategy of semiochemical contain- 
ment of $D$. pseudotsugae for $D$. ponderosae. We hypothesized that a systematic program of semiochemical baiting could be used against $D$. ponderosae to contain within prescribed boundaries a growing infestation that could not be logged before brood flight. This paper presents the results of a controlled experiment designed to test this hypothesis.

\section{Materials and Methods}

Five replicates of paired forest blocks, each harbouring $a$. ponderosae infestation, were chosen (Table 1). Three replicates were in the Bulkley Forest District of the Prince Rupert Region (Graphite Creek and Keulsh Rd. blocks), and two were in the Cranbrook Forest District of the Nelson Region (Plumbob Rd., Suzanne Lk., and Fish Lk. Jn. blocks). The paired blocks were selected as much as possible for similarities in area, stocking, tree size and component of susceptible lodgepole pine (Table 1), as well as for similar levels of infestation (red trees) in 1981 (Table 2). In addition, two blocks without paired controls, Bristol Rd. in the Bulkley Forest District and West Yahk River in the Kootenay Forest District, Nelson Forest Region (Table 1) were selected for treatment.

The experiment was set up in the Prince Rupert Region on 14-17 June and in the Nelson Forest Region on 21-23 June, 1982, well before the first emergence was expected. Well marked lines were established by compass at $50 \mathrm{~m}$ intervals through each block. Every $50 \mathrm{~m}$, a tree on or within $15 \mathrm{~m}$ of the compass line was marked with paint, and in the experimental blocks, baited with semiochemicals. The baiting system employed a foldable, aluminum holder nailed to the north side of the tree. The holder contained vials releasing myrcene and trans-verbenol at laboratory-determined rates of 17 and $2 \mathrm{mg} /$ day, respectively, and a capillary tube releasing exobrevicomin at $0.5 \mathrm{mg}$ / day (Borden et al. 1983b).

In this systematic method of baiting on a grid basis, a density of 4 baits / ha was achieved. Unless the lack of pine dictated that there was $>50 \mathrm{~m}$ between baited trees, no beetle could emerge from the infestation without flying within 25-30 m of a baited tree.

The experiment was assessed in the Prince Rupert Region on 7-15 September, and in the Nelson Forest Region on 27-29 September, 1982. In each block, a $100 \%$ survey was done for trees attacked by $D$. ponderosae in 1981 (red-topped trees) and 1982 (green-attacked trees). One person in a three person crew walked the compass line and took notes, while the other two searched for infested trees. The diameters at breast height (dbh) of all infested trees were taken, and the attack density on green-attacked trees was counted in two, $20 \times 40 \mathrm{~cm}$ frames held at eye level on the bole. The position of each baited or marked tree, as well as each red-topped and green-attacked tree was plotted on a map.

\section{Results and Discussion}

The semiochemical baiting program had a marked effect on the pattern of the 1982 attack by D. ponderosae. Of particular significance was the fact that for two replicates and for all replicates combined, the ratio of the green-attacked to redtopped trees was significantly higher in the baited than in the control blocks (Table 2). Never was the ratio higher in a control block than in a baited block. Interpreted in another way, there were 250 green-attacked trees for every 100 red-topped trees in the baited blocks, and 180 green-attacked trees for every 100 red-topped trees in the control blocks. This result suggests that the baiting program inhibited beetles from leaving the baited blocks or attracted beetles from outside them. As each block was chosen for its relative isolation from surrounding infestations, the former hypothesis is more likely. An alternative hypothesis that the baiting program induced attack of lesser density on proportionately more trees than in the control blocks is refuted by the nearly equal percentages $(70.5$ and $68.6 \%)$ of the attacked trees that were mass attacked in control and baited blocks, respectively (Table 2 ).

The difference in distribution of infestation caused by semiochemical baiting can be seen in Table 2 and Fig. 1. In each case, the attacked trees were significantly closer to the baited trees in baited blocks than to marked trees in control blocks (Table 2). Between 40.2 and $100 \%$ of the attack ( $\bar{x}=70.9 \%)$ in the experimental blocks was concentrated within a $10 \mathrm{~m}$ radius around the baited trees. In contrast, the majority of attacked trees in the control blocks were in the much larger area from 10-25 $\mathrm{m}$ from the marked trees, reflecting a much greater dispersion (Fig. 1). A similar redistribution of attack was achieved for D. pseudotsugae by Pitman (1973).

Attack beyond $25 \mathrm{~m}$ of the baited or marked trees occurred primarily when there was $>50 \mathrm{~m}$ between suitable pines on or near the compass line. These attacked trees undoubtedly provided focal points for attack which diverted beetles from the baited trees, particularly in the Graphite Creek and Bristol Road blocks. The former area was characterized by diverse forest type and beaver ponds, while the latter had large patches of blowdown as well as numerous swamps. In addition, high brush at Graphite Creek and blowdown at Bristol Road resulted in many baits being placed just above the understory canopy. Thus the odour plumes of the released volatiles probably descended into a stratum at which few beetles were flying, further decreasing the efficacy of the baited trees in these areas, and causing the distribution of attacked trees to approach a pattern more characteristic of that in unbaited blocks (Fig. 1). These results suggests that baiting on a $50 \mathrm{~m}$ grid is preferable to a greater between-tree distance, and that baits should be well above the ground or understory canopy so as to intercept the maximum possible number of flying beetles.

In general, one would not expect a great difference in green-attacked to red-topped ratios between baited and control blocks (Table 2), as D. ponderosae commonly attacks fairly near the trees from which it emerges. Relatively few beetles would migrate further afield, causing an infestation to expand. It appears that the baiting program deterred these beetles from leaving.

In large infestations such as those at Graphite Creek and Bristol Rd., it would be immaterial where the beetles moved within the infestation. Only when beetles approached the periphery and threatened to fly outside the boundaries of the infestation would they present a threat to its expansion. Therefore, we recommend that only small infestations, e.g. 2-20 ha, be baited on a grid basis. Larger infestations could be baited only near their peripheries, e.g. on a 50-150 m deep boundary corridor that would intercept departing beetles, as well as possibly draw in migrating beetles passing near the infestation. This procedure might be supplemented by occasional baiting of a few trees in "hot spots" within the larger infestation.

We conclude that semiochemical baiting for D. ponderosae can be applied immediately on an operational basis, as the cost of baits and labour permits. Optimally, it should be applied on a regional basis, e.g. on an entire drainage, with all infestations that cannot be removed before brood flight baited and removed later. The course of infestations within baited regions could then be followed and compared with events in any regions in which semiochemical baiting is not applied. 
Table 1. Descriptive data on semiochemical-baited and control blocks in interior BC locations. Forestry data taken from BC Forest Service cruises.

\begin{tabular}{|c|c|c|c|c|c|c|c|c|}
\hline \multirow[b]{3}{*}{$\begin{array}{l}\text { Rep. } \\
\text { no. }\end{array}$} & \multirow{3}{*}{$\begin{array}{l}\text { Approximate } \\
\text { location and } \\
\text { description of } \\
\text { block }\end{array}$} & \multirow[b]{3}{*}{ Area } & \multicolumn{4}{|c|}{ Lodgepole pine inventory } & \multirow{2}{*}{\multicolumn{2}{|c|}{$\begin{array}{c}\mathrm{dbh}(\mathrm{cm}) \text { of baited } \\
\text { or marked trees }\end{array}$}} \\
\hline & & & \multirow[b]{2}{*}{$\begin{array}{l}\text { No. trees/ } \\
\text { ha }\end{array}$} & \multirow{2}{*}{$\begin{array}{c}\bar{\chi} \mathrm{dbh} \\
(\mathrm{cm})\end{array}$} & \multicolumn{2}{|c|}{ Net merchantable volume } & & \\
\hline & & & & & $\mathrm{m}^{3} / \mathrm{ha}$ & $\%$ of total vol. & $\overline{\mathbf{x}}$ & Range \\
\hline \multirow[t]{3}{*}{1} & Graphite Ck, $3.5 \mathrm{~km} \mathrm{~W}$ of Moricetown & & & & & & & \\
\hline & Control block & 75.0 & 168 & 29.3 & 115 & 43 & 32.3 & $19.4-56.9$ \\
\hline & Baited block & 63.0 & 224 & 29.1 & 157 & 43 & 32.8 & $24.6-51.2$ \\
\hline \multirow[t]{3}{*}{2} & Keulsh Rd. A, $45 \mathrm{~km} \mathrm{~N}$ of Smithers & & & & & & & \\
\hline & Control block & 7.3 & 92 & 41.8 & 134 & 29 & 40.8 & $29.5-55.0$ \\
\hline & Baited block & 8.0 & 403 & 32.8 & 299 & 71 & 40.1 & $27.9-53.7$ \\
\hline \multirow[t]{3}{*}{3} & Keulsh Rd. B, $45 \mathrm{~km} \mathrm{~N}$ of Smithers & & & & & & & \\
\hline & Control block & 5.5 & 230 & 29.0 & 143 & 58 & 37.8 & $24.0-51.8$ \\
\hline & Baited block & 9.8 & 193 & 38.7 & 225 & 63 & 33.8 & $20.7-44.5$ \\
\hline \multirow[t]{3}{*}{4} & Plumbob Rd., $48 \mathrm{~km} \mathrm{~S}$ of Cranbrook & & & & & & & \\
\hline & Control block & 9.7 & 434 & 25.0 & 193 & 82 & 25.2 & $17.8-35.8$ \\
\hline & Baited block & 3.8 & 334 & 28.2 & 195 & 100 & 39.0 & $22.9-39.2$ \\
\hline \multirow[t]{4}{*}{5} & Fish Lk Jn, $45 \mathrm{~km} \mathrm{~S}$ of Cranbrook & & & & & & & \\
\hline & Control block & 8.8 & 574 & 20.6 & 129 & 78 & 28.3 & $22.0-39.6$ \\
\hline & Suzanne Lk, $45 \mathrm{~km} \mathrm{~S}$ of Cranbrook & & & & & & & \\
\hline & Baited block & 7.0 & 606 & 18.5 & 109 & 78 & 25.5 & $19.2-37.5$ \\
\hline \multirow[t]{2}{*}{-} & Bristol Rd., $36 \mathrm{~km} \mathrm{~N}$ of Smithers & & & & & & & \\
\hline & Baited block & 31.0 & 281 & 31.7 & 207 & 67 & 37.9 & $22.1-48.9$ \\
\hline \multirow[t]{2}{*}{-} & West Yahk R., 27 km S of Yahk & & & & & & & \\
\hline & Baited block & 3.0 & 350 & 25.9 & 130 & 100 & 34.6 & $23.7-49.0$ \\
\hline
\end{tabular}

Table 2. Attack by $D$. ponderosae in paired baited and control blocks and in two baited blocks with no paired controls.

\begin{tabular}{|c|c|c|c|c|c|c|c|c|c|c|c|c|}
\hline \multirow{4}{*}{$\begin{array}{l}\text { Rep. } \\
\text { no. }\end{array}$} & \multirow{4}{*}{$\begin{array}{l}\text { Location } \\
\text { and } \\
\text { treatment }\end{array}$} & \multirow{2}{*}{\multicolumn{5}{|c|}{ Marked or baited trees }} & \multicolumn{4}{|c|}{ Surrounding trees } & \multirow{4}{*}{$\begin{array}{l}\text { No. red } \\
(1981) \\
\text { trees }\end{array}$} & \multirow{4}{*}{$\begin{array}{c}\text { Green: red } \\
\text { (1982: 1981) } \\
\text { ratio }^{c}\end{array}$} \\
\hline & & & & & & & \multirow{3}{*}{$\begin{array}{c}\text { No. } \\
\text { attacked }\end{array}$} & \multirow{2}{*}{\multicolumn{2}{|c|}{ Mass attacked ${ }^{a}$}} & \multirow{3}{*}{$\begin{array}{c}\overline{\mathrm{x}} \text { Distance } \pm S D \\
\text { from nearest } \\
\text { baited } \\
\text { or marked tree }\end{array}$} & & \\
\hline & & \multirow{2}{*}{ No. } & \multicolumn{4}{|c|}{ Attacked Mass attacked ${ }^{\mathrm{a}}$} & & & & & & \\
\hline & & & No. & $\%$ & No. & $\%$ & & No. & $\%$ & & & \\
\hline 1 & $\begin{array}{l}\text { Graphite Ck. } \\
\text { Control } \\
\text { Baited }\end{array}$ & $\begin{array}{l}239 \\
188\end{array}$ & $\begin{array}{r}9 \\
90\end{array}$ & $\begin{array}{r}3.7 \\
47.8\end{array}$ & $\begin{array}{r}4 \\
49\end{array}$ & $\begin{array}{r}1.7 \\
26.1\end{array}$ & $\begin{array}{l}414 \\
317\end{array}$ & $\begin{array}{l}291 \\
219\end{array}$ & $\begin{array}{l}70.2 \\
69.0\end{array}$ & $\begin{array}{l}18.8 \pm 9.0 \\
14.3 \pm 8.7^{*}\end{array}$ & $\begin{array}{l}200 \\
131\end{array}$ & $\begin{array}{l}2.1 \\
3.1^{* *}\end{array}$ \\
\hline 2 & $\begin{array}{l}\text { Keulsh Rd. A } \\
\text { Control } \\
\text { Baited }\end{array}$ & $\begin{array}{l}30 \\
32\end{array}$ & $\begin{array}{r}1 \\
21\end{array}$ & $\begin{array}{r}3.3 \\
65.6\end{array}$ & $\begin{array}{r}1 \\
17\end{array}$ & $\begin{array}{r}3.3 \\
53.1\end{array}$ & $\begin{array}{l}32 \\
47\end{array}$ & $\begin{array}{l}27 \\
35\end{array}$ & $\begin{array}{l}84.3 \\
74.4\end{array}$ & $\begin{array}{l}22.1 \pm 8.3 \\
12.0 \pm 9.2^{* *}\end{array}$ & $\begin{array}{l}37 \\
58\end{array}$ & $\begin{array}{l}0.9 \\
1.2\end{array}$ \\
\hline 3 & $\begin{array}{l}\text { Keulsh Rd. B } \\
\text { Control } \\
\text { Baited }\end{array}$ & $\begin{array}{l}41 \\
21\end{array}$ & $\begin{array}{r}0 \\
19\end{array}$ & $\begin{array}{r}0.0 \\
90.4\end{array}$ & $\begin{array}{r}0 \\
12\end{array}$ & $\begin{array}{r}0.0 \\
57.1\end{array}$ & $\begin{array}{l}15 \\
28\end{array}$ & $\begin{array}{l}12 \\
16\end{array}$ & $\begin{array}{l}80.0 \\
57.1\end{array}$ & $\begin{array}{c}20.5 \pm 3.2^{* *} \\
8.5 \pm 8.5\end{array}$ & $\begin{array}{l}16 \\
26\end{array}$ & $\begin{array}{l}0.9 \\
1.8\end{array}$ \\
\hline 4 & $\begin{array}{l}\text { Plumbob Rd. } \\
\text { Control } \\
\text { Baited }\end{array}$ & $\begin{array}{l}35 \\
12\end{array}$ & $\begin{array}{r}0 \\
11\end{array}$ & $\begin{array}{r}0.0 \\
91.6\end{array}$ & $\begin{array}{r}0 \\
11\end{array}$ & $\begin{array}{r}0.0 \\
91.6\end{array}$ & $\begin{array}{l}42 \\
43\end{array}$ & $\begin{array}{l}30 \\
32\end{array}$ & $\begin{array}{l}71.4 \\
74.4\end{array}$ & $\begin{array}{r}16.6 \pm 6.1 \\
8.6 \pm 6.2^{* *}\end{array}$ & $\begin{array}{l}39 \\
24\end{array}$ & $\begin{array}{l}1.1 \\
1.7^{\circ}\end{array}$ \\
\hline 5 & $\begin{array}{l}\text { Fish Lk. Jn/ } \\
\text { Suzanne Lk } \\
\text { Control } \\
\text { Baited }\end{array}$ & $\begin{array}{l}28 \\
27\end{array}$ & $\begin{array}{r}0 \\
24\end{array}$ & $\begin{array}{r}0.0 \\
88.8\end{array}$ & $\begin{array}{r}0 \\
22\end{array}$ & $\begin{array}{r}0.0 \\
81.5\end{array}$ & $\begin{array}{l}57 \\
23\end{array}$ & $\begin{array}{l}35 \\
12\end{array}$ & $\begin{array}{l}61.4 \\
52.1\end{array}$ & $\begin{array}{c}15.9 \pm 8.0 \\
3.4 \pm 1.3^{* *}\end{array}$ & $\begin{array}{l}20 \\
15\end{array}$ & $\begin{array}{l}2.9 \\
3.1\end{array}$ \\
\hline Summ & $\begin{array}{l}\text { paired blocks } \\
\text { Control } \\
\text { Baited }\end{array}$ & $\begin{array}{l}373 \\
280\end{array}$ & $\begin{array}{r}10 \\
165\end{array}$ & $\begin{array}{r}2.7 \\
58.9\end{array}$ & $\begin{array}{r}5 \\
111\end{array}$ & $\begin{array}{r}1.3 \\
39.6\end{array}$ & $\begin{array}{l}560 \\
458\end{array}$ & $\begin{array}{l}395 \\
314\end{array}$ & $\begin{array}{l}70.5 \\
68.6\end{array}$ & $\begin{array}{l}18.5 \pm 8.6 \\
12.5 \pm 8.8^{*}\end{array}$ & $\begin{array}{l}312 \\
254\end{array}$ & $\begin{array}{l}1.8 \\
2.5^{* *}\end{array}$ \\
\hline- & $\begin{array}{l}\text { Bristol Rd. } \\
\text { Baited }\end{array}$ & 110 & 54 & 49.0 & 21 & 19.1 & 48 & 18 & 37.5 & $18.5 \pm 18.4$ & 72 & 1.4 \\
\hline- & $\begin{array}{l}\text { West Yahk R. } \\
\text { Baited }\end{array}$ & 12 & 12 & 100.0 & 12 & 100.0 & 42 & 24 & 57.1 & $9.4 \pm 9.3$ & 27 & 2.0 \\
\hline
\end{tabular}

aMass attacked trees arbitrarily designated as those with $\geqslant 5$ attacks in two, $2 \times 40 \mathrm{~cm}$ frames, an attack density of $30.75 / \mathrm{m}^{2}$

bSigniticant difference (t-lest) between paired means indicated by $*, p<0.01$

"Baited trees included in 1982 attack. Significant difference $\left(x^{2}\right.$ test) between control and baited blocks indicated by $;., p<0.05$ and $\cdots, p<0.01$ 


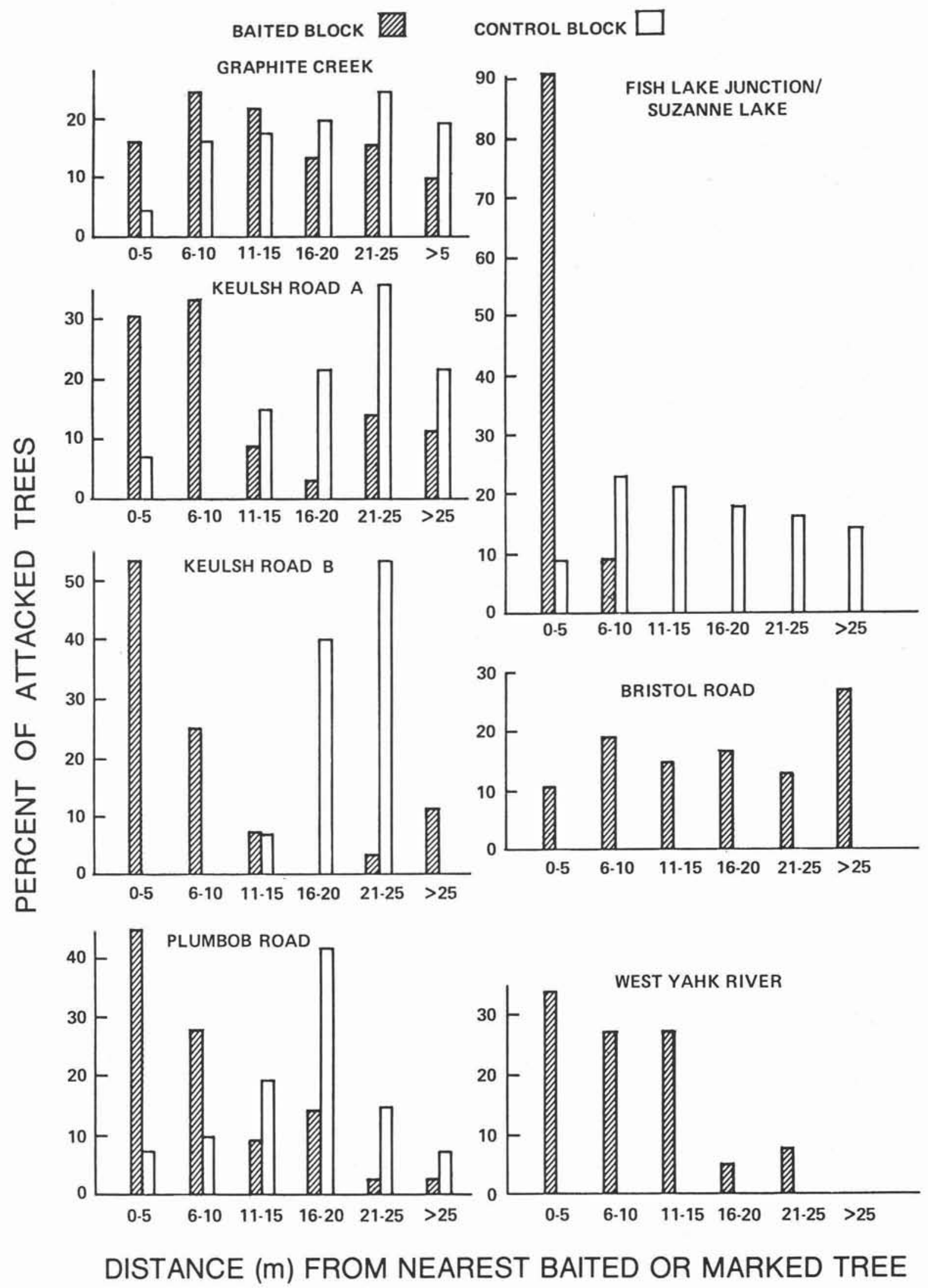

Figure 1. Distribution of attack by D. ponderosae surrounding baited trees (baited blocks) or marked trees (control blocks). 


\section{Acknowledgments}

We thank: H.D. Pierce, Jr. for assistance in providing semiochemicals of verified authenticity and purity: M.A. Bowman, M.J. Buirs, L.H. Graf, W.S. Jensen, E.K. Kavanagh, C.N. O'Conner and A.J. Stock for assistance in the laboratory and the field; and the BC Forest Service for welcoming and facilitating research in the Prince Rupert and Nelson Forest Regions.

\section{References}

Borden, J.H., J.E. Conn, L.M. Friskie, B.E. Scott, L.J. Chong, H.D. Pierce, Jr. and A.C. Oehlschlager, 1983a. Semiochemicals for the mountain pine beetle. Dendroctonus ponderosae, in British Columbia: baited tree studies. Can. J. For. Res, 13: 325-333.

Borden, J.H., L.J. Chong and M.C. Fuchs. 1983b. The application of semiochemicals in post-logging manipulation of the mountain pine beetle. Dendroctonus ponderosae. J. Econ. Entomol. (in press).

Conn, J.E., J.H. Borden, B.E. Scott, L.M. Friskie, H.D. Pierce, Jr. and A.C. Oehlschlager. 1983. Semiochemicals for the mountain pine beetle, Dendrotonus ponderosae, in British Columbia: field trapping studies. Can. J. For. Res. 13: 320-324.
Dyer, E.D.A. 1975. Frontalin attractant in stands infested by the spruce beetle, Dendroctonus rufipennis (Coleoptera:Scolytidae). Can. Entomol. 107: 979-988.

McGregor, M. 1982. The current situation of the mountain pine beetle in the United States and the resources involved. pp. 16-21. In D.M. Shrimpton (ed.) Proceedings of the joint Canada/USA workshop on mountain pine beetle related problems in western North America. Environ. Canada, Can. For. Serv. Pap. No. $\mathrm{BC}-\mathrm{X}-230$

Pitman, G.B. 1973. Further observations on Douglure in a Dendroctonus pseudotsugae management system. Environ. Entomol. 2: $109-112$.

Ringold, G.B., P.J. Gravelle, D. Miller, M.M. Furniss and M.D. McGregor. 1975. Characteristics of Douglas-fir beetle infestation in northern Idaho resulting from treatment with Douglure. USDA, For. Serv. Res. Note INT-189.

Safranyik, L., D.M. Shrimpton and H.S. Whitney, 1974. Management of lodgepole pine to reduce losses from the mountain pine beetle. Environ. Canada, Can. For. Serv. For. Tech. Rep. No. 1

Van Sickle, G.A. 1982. The mountain pine beetle situation in Canada 1981. pp. 13-15. In. D.M. Shrimpton (ed.). Proceedings of the joint Canada/USA workshop on mountain pine beetle related problems in western North America. Environ. Canada, Can. For. Serv. Pap. No. BC-X-230.

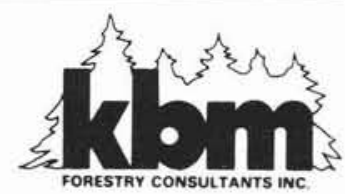

360 mooney street

thunder bay, ontario

$$
\text { P7B 5R4 }
$$

\section{REFORESTATION EQUIPMENT \\ - Sales Service Parts Repair}

\section{REGENERATION \& SITE PREPARATION}

- Contract Assessment Consulting

807-344-0811 telex 073-4603

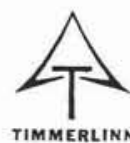

Tel.: (819) 326-3559

TIMMERLIN

\section{TIMMERLINN LIMTreE}

PROFESSIONAL AND TECHNICAL SERVICES

IN FORESTRY AND ENVIRONMENTAL SCIENCES

R.R. No. 2, STE. AGATHE DES MONTS, QUE. J8C $2 Z 8$ 